\title{
SEED DORMANCY AND CONE AND SEED MORPHOLOGY OF SYRIAN JUNIPER (JUNIPERUS DRUPACEA LABILL.) IN THE EASTERN MEDITERRANEAN REGION OF TURKEY
}

\section{DORMANTNOST SJEMENA I MORFOLOGIJA BOBULJASTIH ČEŠERA I SJEMENA KOŠTUNIČAVE BOROVICE (JUNIPERUS DRUPACEA Labill.) U ISTOČNO MEDITERANSKOM PODRUČJU TURSKE}

Zeynep YAVUZ, Mustafa YILMAZ

\begin{abstract}
Summary
Syrian juniper, Juniperus drupacea Labill., is an Eastern Mediterranean tree species which belongs to the Cupressaceae family and Juniperoidae sub-family. The current geographical range of $J$. drupacea covers the southern parts of the Peloponnese in Greece, the southern parts of Asia Minor and the mountains of Syria and Lebanon. The main part of the species range in Turkey is divided into several centres the most important being located in the Taurus, Anti-Taurus and Amanos mountains. It is a dioecious tree, with conical crown, that reaches 10-20 (40) $\mathrm{m}$ in height. The fleshy cones are ovoid to globose, $20-25 \mathrm{~mm}$ in diameter, brownish-purple or bluish-black, glaucosus and pruniose when ripe in the second year. They mostly have 3 seeds forming a characteristic drupe-like stone. The natural regeneration of Syrian juniper is very difficult because of animal consumption, grazing and the united seeds into the woody structure. This study was carried out to determine the seed and cone morphology and seed physiology of Syrian juniper, Juniperus drupacea Labill., from three provenances (Kahramanmaraş, Mersin, Adana) in the Eastern Mediterranean region of Turkey. In total 11 morphological traits were measured. The average cone length, cone diameter, and cone weight were $22.49 \mathrm{~mm}, 20.86 \mathrm{~mm}$ and $4.659 \mathrm{~g}$, respectively. The average seed length, width, thickness, weight and pulp weight were $10.07 \mathrm{~mm}, 3.30 \mathrm{~mm}, 2.77 \mathrm{~mm} 0.045 \mathrm{~g}$ and $2.220 \mathrm{~g}$ in order. After morphological analysis, a series of experiments was conducted to identify the best stratification treatment for breaking dormancy in Syrian juniper seeds. The highest germination percentage was obtained after warm and cold stratification (80.7\%). The seeds prechilled 8 weeks and soaked $500 \mathrm{ppm} \mathrm{GA}_{3}$ also demonstrated high germination percentage. The current study demonstrated that $J$. drupacea seeds has morphophysiological dormancy.
\end{abstract}

KEY WORDS: Juniperus drupacea, cone and seed morphology, seed dormancy

\section{INTRODUCTION}

\section{UVOD}

Syrian juniper, Juniperus drupacea Labill., is an Eastern Mediterranean tree species which belongs to the Cupres- saceae family and Juniperoidae sub-family. The current geographical range of J. drupacea covers the southern parts of the Peloponnese in Greece, the southern parts of Asia Minor and the mountains of Syria and Lebanon. The main part 
of the species range in Turkey is divided into several centres the most important being located in the Taurus, Anti-Taurus and Amanos mountains. It usually occurs at 600-1800 (2050) m altitude on rocky and lime terrains in Antalya, Karaman, Konya, Mersin, Adana, Hatay, Osmaniye and Kahramanmaraş. Mostly forms mixed stands with Crimean pine (Pinus nigra J.F.Arnold subsp. pallasiana /Lamb./ Holmboe), Turkish pine (Pinus brutia Ten), cedar of Lebanon (Cedrus libani A. Rich.), Taurus fir (Abies cilicica /Antoine et Kotschy/ Carrière), oaks (QuercusL spp.) and junipers (JuniperusL. spp.). It is a dioecious tree, with conical crown, that reaches 10-20 (40) $\mathrm{m}$ in height. Bark is brown and cinnamon beneath, exfoliating in narrowing strips. Leaves are acicular, 10-25 mm long and 3-4 mm wide, with two white bands on the above. Needles are arranged in alternate whorls of three. The seed cones of Syrian juniper are the largest of any juniper species. They are ovoid to globose, 20-25 mm in diameter, brownish-purple or bluish-black, glaucosus and pruniose when ripe in the second year. The fleshy cones mostly have 3 seeds forming a characteristic drupe-like stone (Vidaković, 1991; Adams, 2014; Sobierajska et al., 2016). Likewise, the seeds are very attractive food source for animals. The natural regeneration of Syrian juniper is very difficult because of animal consumption, grazing and the united seeds into the woody structure. In nature, seeds can germinate in period of 3-5 years (Browicz, 1982; Yaltırlk, 1988; Gültekin, 2007; Gültekin et al. 2004). In the south of Turkey, J. drupacea cones are traditionally used in molasses processing.

Morphological data are still very important in many fields of plant sciences (Kaplan, 2001; Douaihy et al., 2012; Poljak et al., 2015): different taxon delimitation (Sękiewicz et al., 2016), population variability (Brus et al. 2011, 2016; Douaihy et al., 2012),cultivar characterisation (Poljak et al., 2016) and selection (Polat and Özkaya, 2005), as well as in morphological and physiological seed characterisation (Powell, 2010; Yilmaz and Yüksel, 2014; Drvodelić et al., 2015; Daneshvar et al., 2016). In fact, according to the Powell (2010) in the past few years there is an increased interest for seed science, i.e morphological and physiological characteristics of seeds and their capacity to germinate and survive.

Seeds must be alive and matured as physiological and morphological for germination. Some alive seeds can't germinate despite they have optimal conditions (moisture, temperature, oxygen light/dark). This condition is named as seed dormancy (Schmidt, 2000; Bewley and Black 2013). Seed dormancy seperated into 5 basic classes. Physiological dormancy, morphological dormancy, morphophysiological dormancy, physical dormancy and combinational (physical and physiological) dormancy (Baskin and Baskin, 2004; Bonner, 2008). Juniperus species seeds show different dormancy characteristics like physiological dormancy $(J$. phoenicea) or morphophysiological dormancy (J. polycarpos) so it is difficult to propogate from seeds (Broom, 2003; Daneshvar et al. 2016; Al-Ramamneh et al. 2012).

The aim of this study was to determine seed and cone morphology, and to search the dormancy depth and level and proper dormancy-breaking pre-treatments in Syrian juniper seeds from three provenances in the eastern Mediterranean region of Turkey. The effect of $\mathrm{GA}_{3}$ hormone on the germination behaviour of seeds was also tested.

\section{MATERIAL AND METHODS MATERIJALI I METODE}

The cones were collected from three provenances (MersinMut, Kahramanmaraş-Andırın, Adana-Kozan) in Turkey in February and March 2014 (Table 1). The seeds, for dormancy treatments and exogenous application of hormones, were extracted from the cones by hammering the cones, and then they were air dried to 5.4 MC at ambient temperature for two days. The air dried seeds were stored in the closed bottles in the refrigerator till use.

A Syrian juniper cone is composed of three parts. The pulp carpel, woody carpel and seed. From each provenance 50 cones were randomly selected and measured. Firstly cone traits (cone length, cone diameter, cone weight) were measured. Then, pulp part was removed and woody carpel was measured (length, diameter and weight). Finally woody part was broken, the seeds were extracted and the number of seeds and seed weight were determined. In this way, the weight percentage of pulp part, woody part, and seed part in a cone were identified. Furthermore, 50 seeds from each provenance were randomly chosen seed length, width and thickness were measured. 1000-seed weight was also found from 800 seeds $\left(8^{\star} 100\right)$ according to the ISTA rules (1996).

To found out the dormancy level and pre-treatment requirements, seeds from three different provenances were subjected 0 (control), 4 (4w), 8 (8w), 12 (12w) and $16(16 w)$

Table 1. Study area.

Tablica 1. Područje istraživanja

$\begin{array}{lccc}\text { Provenances } & \begin{array}{c}\text { Latitude } \\ \text { Provenijencija }\end{array} & \begin{array}{c}\text { Longitude } \\ \text { Geog rafska širina }\end{array} & \begin{array}{c}\text { Altitude } \\ \text { Nadmorska visina (m) }\end{array} \\ \text { Mersin-Mut } & 36^{\circ} 40^{\prime} & 33^{\circ} 44^{\prime} & 1116 \\ \text { Kahramanmaraş-Andirın } & 37^{\circ} 45^{\prime} & 36^{\circ} 42^{\prime} & 943 \\ \text { Adana-Kozan } & 37^{\circ} 38^{\prime} & 35^{\circ} 50^{\prime} & 895\end{array}$



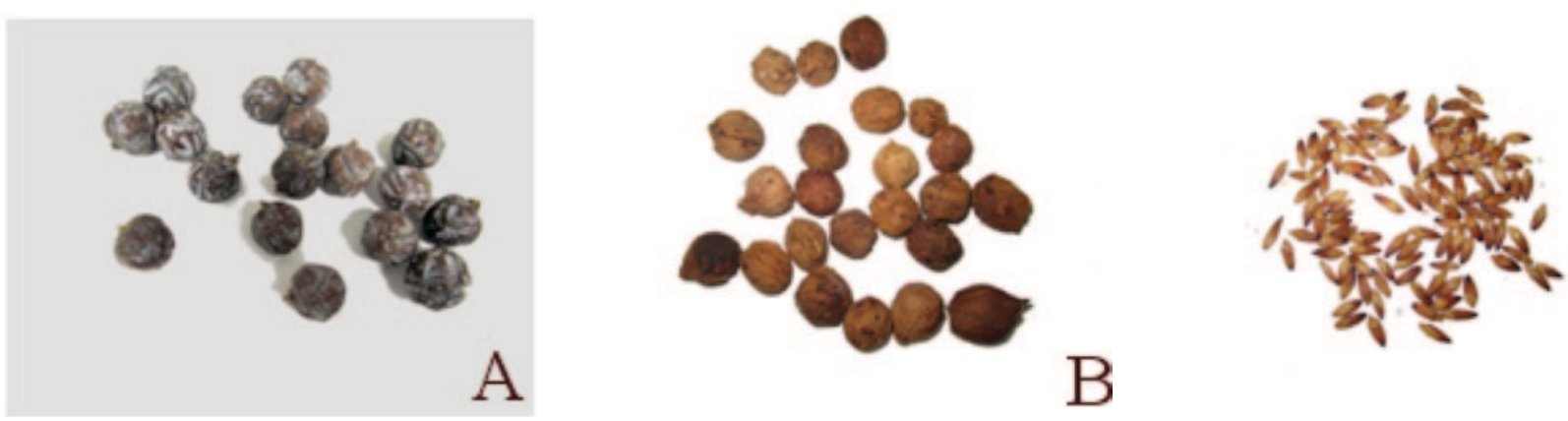

B
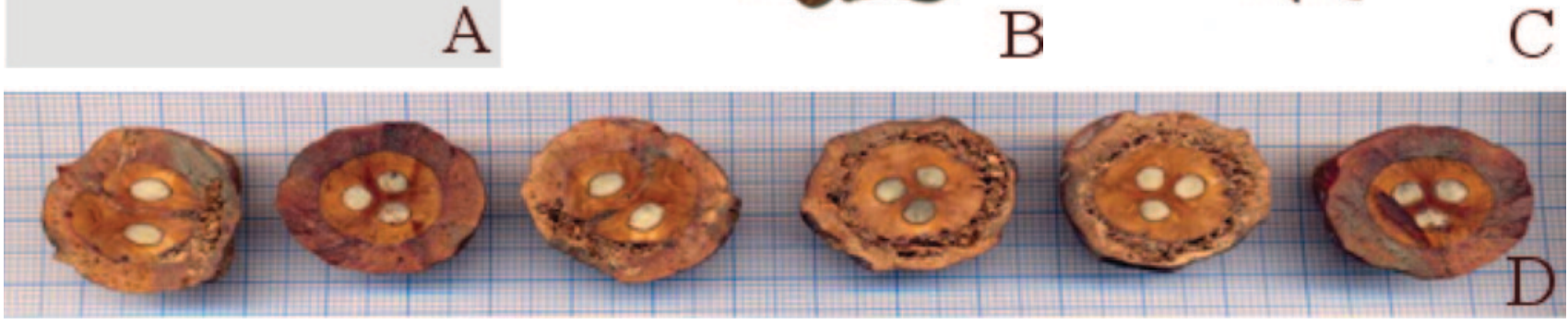

Figure 1. (A) cones; (B) woody part of the cones; (C) seeds; and (D) cross section of Syrian juniper cones.

Slika 1. (A) bobuljasti češeri; (B) drvenasti dijelovi bobuljastih češera; (C) sjeme; i (D) bobuljasti češeri koštuničaste borovice na poprečnom presjeku.

weeks pre-chilling at $4{ }^{\circ} \mathrm{C}$, as well as the 4 weeks warm incubation at $12^{\circ} \mathrm{C}$ subsequently 9 weeks cold stratification at $4{ }^{\circ} \mathrm{C}(4 \mathrm{wW}+9 \mathrm{w})$.

Germination tests were done in $11 \mathrm{~cm}$ diameter Petri dishes on two layer of filter paper moistened with distilled water with 150 seeds $(3 \times 50)$ at $12{ }^{\circ} \mathrm{C}$. The seeds were checked every 4 days and the germinated seeds were recorded and removed. Germination tests were continued for 92 days. The seeds were removed from Petri dishes after their radicles were elongated for $3 \mathrm{~mm}$.

To investigate the effects of $\mathrm{GA}_{3}$ on the dormancy and the germination, seeds from two different provenances (Adana and Mersin) were tested. Two types of seed were used, nonpre-chilled and 8 weeks pre-chilled. Both types of seed were subjected to different $\mathrm{GA}_{3}$ hormone doses (100 ppm and $500 \mathrm{ppm}$ ) for 24 hours.

Germination percentage (GP) and mean germination time (MGT) were calculated according to following formulas (Bewley et al., 2013):

$$
\mathrm{GP}(\%)=\left(\sum \mathrm{n}_{\mathrm{i}} / \mathrm{N}\right) \times 100
$$

where GP is the germination percentage, $n_{i}$ is the number of germinated seeds at week $\mathrm{i}$, and $\mathrm{N}$ is the total number of incubated seeds per tests; and

$$
\operatorname{MGT}=\sum\left(\mathrm{t}_{\mathrm{i}} \cdot \mathrm{n}_{\mathrm{i}}\right) / \sum \mathrm{n}_{\mathrm{i}}
$$

where MGT is the mean germination time, $\mathrm{t}_{\mathrm{i}}$ is the number of weeks from the beginning of the test, and $n_{i}$ is the number of germinated seeds recorded on week $t_{i}$.

Morphological characteristics of cones and seeds, germination percentage as well as mean germination time were analyzed using ANOVA. The percent values (GP) were transformed using arc sin square root before variance analyses.

\section{RESULTS}

\section{REZULTATI}

The average cone length, cone diameter and cone weight were $22.49 \mathrm{~mm}, 20.86 \mathrm{~mm}$ and $4.659 \mathrm{~g}$ respectively. There were no significant differences between provenances in terms of cone length and cone diameter. Adana provenance had the heaviest cone in average. Average woody part length, diameter and weight were $17.62 \mathrm{~mm}, 14.76 \mathrm{~mm}$ and $2.34 \mathrm{~g}$ in order. The average pulp weight was $2.22 \mathrm{~g}$. The average number of seeds were 2.2 and the average seeds weight $0.097 \mathrm{~g}$. Average woody part, pulp part and seed weight percentage in a cone were $50.69 \%, 47.18 \%$ and $2.12 \%$ respectively.

Average 1000-seed weight for three provenances was 44.66 $\mathrm{g}$ at about 5.4\%MC. The average seed length, width, thickness and weight were $10.07 \mathrm{~mm}, 3.30 \mathrm{~mm}, 2.77 \mathrm{~mm}$ and $0.045 \mathrm{~g}$ respectively. There were no significant differences between the provenances in terms of seed width and thickness. Kahramanmaraş provenance had the heaviest seed in average (Table 2).

Pre-chilling applications of $4 \mathrm{w}$ and $8 \mathrm{w}$ were inadequate for breaking the dormancy. By contrast, $12 \mathrm{w}$ and $16 \mathrm{w}$ pre-chilling applications increased the germination percentages, but these treatments didn't eliminate the dormancy completely. 4 week warm stratification subsequently with $9 \mathrm{w}$ pre-chilling resulted in the highest germination percentage. After the $0-w, 4-w, 8-w, 12-w, 16-w$, and $4 w$ warm stratification +9 $\mathrm{w}$ pre-chilling average germination percentages were $6 \%$, $15.3 \%, 14.2 \%, 26.9 \%, 27.8 \%, 65.3 \%$ respectively (Table3). Mean germination time of seeds after different applications at germination temperature at $12{ }^{\circ} \mathrm{C}$ is presented in Table 4 . Gibberellic acid was applied to 8-w pre-chilled and non-prechilled seeds which were collected from Adana and Mersin provenance. The hormone didn't increase germination percentage innon-pre-chilled seeds. On the contrary, this hor- 
Table 2. Morphological characteristics of J. drupacea seeds and cones.

Tablica 2. Morfološke značajke bobuljastih češera i sjemena J. drupacea.

\begin{tabular}{|c|c|c|c|c|c|c|c|c|c|c|c|}
\hline \multirow{2}{*}{$\begin{array}{l}\text { Provenance } \\
\text { Provenijencija }\end{array}$} & \multicolumn{3}{|c|}{$\begin{array}{c}\text { Cone } \\
\text { Bobuljasti-češer }\end{array}$} & \multicolumn{3}{|c|}{$\begin{array}{l}\text { Woody part of the cone } \\
\text { Drvenasti dio } \\
\text { bobuljastog češera }\end{array}$} & \multicolumn{4}{|c|}{$\begin{array}{l}\text { Seed } \\
\text { Sjeme }\end{array}$} & \multirow{2}{*}{$\begin{array}{l}\text { Fleshy part of the cone } \\
\text { Mesnati dio } \\
\text { bobuljastog češera } \\
\text { Weight } \\
\text { Težina } \\
\text { (g) }\end{array}$} \\
\hline & $\begin{array}{l}\text { Length } \\
\text { Dužina } \\
(\mathrm{mm})\end{array}$ & $\begin{array}{l}\text { Width } \\
\text { Širina } \\
(\mathrm{mm})\end{array}$ & $\begin{array}{l}\text { Weight } \\
\text { Težina } \\
\text { (g) }\end{array}$ & $\begin{array}{l}\text { Length } \\
\text { Dužina } \\
(\mathrm{mm})\end{array}$ & $\begin{array}{l}\text { Width } \\
\text { Sirina } \\
\text { (mm) }\end{array}$ & $\begin{array}{l}\text { Weight } \\
\text { Težina } \\
\text { (g) }\end{array}$ & $\begin{array}{l}\text { Length } \\
\text { Dužina } \\
(\mathrm{mm})\end{array}$ & $\begin{array}{l}\text { Width } \\
\text { Širina } \\
(\mathrm{mm})\end{array}$ & $\begin{array}{l}\text { Thickness } \\
\text { Debljina } \\
(\mathrm{mm})\end{array}$ & $\begin{array}{l}\text { Weight } \\
\text { Težina } \\
\text { (g) }\end{array}$ & \\
\hline Maraş & $22.42 a^{1}$ & $20.58 a$ & $4.648 \mathrm{ab}$ & $17.71 \mathrm{a}$ & $15.20 \mathrm{a}$ & $2.485 \mathrm{a}$ & $10.30 \mathrm{a}$ & $3.33 \mathrm{a}$ & $2.81 \mathrm{a}$ & $0.048 \mathrm{a}$ & $2.047 \mathrm{~b}$ \\
\hline Adana & $22.82 \mathrm{a}$ & 20.91 a & $4.861 \mathrm{a}$ & $17.58 \mathrm{a}$ & $14.88 \mathrm{a}$ & $2.412 \mathrm{a}$ & $10.21 \mathrm{a}$ & $3.25 \mathrm{a}$ & $2.74 \mathrm{a}$ & $0.042 \mathrm{~b}$ & $2.355 \mathrm{a}$ \\
\hline Mersin & $22.23 \mathrm{a}$ & $21.08 \mathrm{a}$ & $4.469 \mathrm{~b}$ & $17.57 \mathrm{a}$ & $14.20 \mathrm{~b}$ & & $9.69 \mathrm{~b}$ & $3.33 \mathrm{a}$ & $2.76 \mathrm{a}$ & $0.044 \mathrm{~b}$ & $2.256 a b$ \\
\hline Average - Prosječno & 22.49 & 20.86 & 4.659 & 17.62 & 14.76 & 2.342 & 10.07 & 3.30 & 2.77 & 0.045 & 2.220 \\
\hline
\end{tabular}

${ }^{1}$ The values on the same column followed by the same letters are not significantly different $(p<0.05)$.

${ }^{1}$ Vrijednosti u istoj koloni označene istim slovom ne razlikuju se na razini signifikantnosti od ( $p<0.05$ ).

Table 3. The germination percentages after various pre-treatments at $12^{\circ} \mathrm{C}$.

Tabela 3. Postotak klijavosti pri temperaturi od $12^{\circ} \mathrm{C}$ nakon različite predsjetvene pripreme.

\begin{tabular}{|c|c|c|c|c|c|c|c|}
\hline \multirow{2}{*}{$\begin{array}{l}\text { Provenance } \\
\text { Provenijencija }\end{array}$} & \multicolumn{6}{|c|}{$\begin{array}{l}\text { Pre-chilling duration } \\
\text { Trajanje stratifikacije }\end{array}$} & \multirow{2}{*}{$\begin{array}{c}\text { Average } \\
\text { Prosječnc }\end{array}$} \\
\hline & $\begin{array}{c}0 \text { (control) } \\
\text { kontrola }\end{array}$ & $\begin{array}{l}4 \text { weeks } \\
4 \text { tjedna }\end{array}$ & $\begin{array}{l}8 \text { weeks } \\
8 \text { tjedana }\end{array}$ & $\begin{array}{l}12 \text { weeks } \\
12 \text { tjedana }\end{array}$ & $\begin{array}{l}16 \text { weeks } \\
16 \text { tjedana }\end{array}$ & $4 w W S+9 w$ & \\
\hline Adana & $8.7 d^{1}$ & $16.0 \mathrm{c}$ & $11.3 \mathrm{~cd}$ & $13.3 \mathrm{~cd}$ & $22.7 \mathrm{~b}$ & $45.3 \mathrm{a}$ & $19.6 C^{2}$ \\
\hline Mersin & $9.3 \mathrm{e}$ & $19.3 \mathrm{~d}$ & $19.3 \mathrm{~d}$ & $44.0 \mathrm{~b}$ & $28.0 \mathrm{c}$ & $70.0 \mathrm{a}$ & $31.7 \mathrm{~A}$ \\
\hline Maraş & $0.0 \mathrm{e}$ & $10.7 \mathrm{~d}$ & $12.0 \mathrm{~d}$ & $23.3 \mathrm{c}$ & $32.7 \mathrm{~b}$ & 80.7 a & $26.6 \mathrm{~B}$ \\
\hline Average - Prosječno & $6.0 \mathrm{~d}$ & $15.3 \mathrm{c}$ & $14.2 \mathrm{c}$ & $26.9 \mathrm{~b}$ & $27.8 \mathrm{~b}$ & $65.3 \mathrm{a}$ & \\
\hline
\end{tabular}

${ }^{1}$ The values on the same line followed by the same letters are not significantly different $(p<0.05)$.

${ }^{1}$ Vrijednosti u istom retku označene istim malim slovom ne razlikuju se na razini signifikantnosti od $(p<0.05)$.

${ }^{2}$ The values on the same column followed by the same capital letters are not significantly different $(p<0.05)$.

${ }^{2}$ Vrijednosti u istoj koloni označene istim velikim slovom ne razlikuju se na razini signifikantnosti od ( $\left.p<0.05\right)$.

Table 4. Mean germination time of seeds after different applications at germination temperature at $12^{\circ} \mathrm{C}$.

Tablica 5. Srednje vrijeme klijanja sjemena J.drupacea pri temperaturi od $12^{\circ} \mathrm{C}$ nakon različite predsjetvene pripreme.

\begin{tabular}{|c|c|c|c|c|c|c|c|}
\hline \multirow{2}{*}{$\begin{array}{l}\text { Provenance } \\
\text { Provenijencija }\end{array}$} & \multicolumn{6}{|c|}{$\begin{array}{l}\text { Pre-chilling duration } \\
\text { Trajanje stratifikacije }\end{array}$} & \multirow{2}{*}{$\begin{array}{c}\text { Average } \\
\text { Prosječno }\end{array}$} \\
\hline & $\begin{array}{c}0 \text { (control) } \\
\text { kontrola }\end{array}$ & $\begin{array}{l}4 \text { weeks } \\
4 \text { tjedna }\end{array}$ & $\begin{array}{l}8 \text { weeks } \\
8 \text { tjedana }\end{array}$ & $\begin{array}{l}12 \text { weeks } \\
12 \text { tjedana }\end{array}$ & $\begin{array}{l}16 \text { weeks } \\
16 \text { tjedana }\end{array}$ & $4 w W S+9 w$ & \\
\hline Adana & $78.0 \mathrm{~d}^{1}$ & $74.4 \mathrm{~d}$ & $54.5 \mathrm{c}$ & $47.1 \mathrm{~b}$ & $42.4 \mathrm{~b}$ & $23.7 \mathrm{a}$ & $53.4 C^{2}$ \\
\hline Mersin & $63.9 \mathrm{~d}$ & $53.6 \mathrm{c}$ & $55.2 \mathrm{c}$ & $41.4 \mathrm{~b}$ & $41.9 \mathrm{~b}$ & $19.1 \mathrm{a}$ & $45.9 \mathrm{~B}$ \\
\hline Maraş & - & $56.1 \mathrm{~d}$ & $53.5 d$ & $37.5 \mathrm{c}$ & $29.2 b$ & $14.0 \mathrm{a}$ & $38.1 \mathrm{~A}$ \\
\hline Average - Prosječno & $70.9 f$ & $61.4 \mathrm{e}$ & $54.4 \mathrm{~d}$ & $42.0 \mathrm{c}$ & $37.8 \mathrm{~b}$ & $18.9 \mathrm{a}$ & \\
\hline
\end{tabular}

${ }^{1}$ The values on the same line followed by the same letters are not significantly different $(p<0.05)$.

${ }^{1}$ Vrijednosti u istom retku označene istim malim slovom ne razlikuju se na razini signifikantnosti od ( $\left.p<0.05\right)$.

${ }^{2}$ The values on the same column followed by the same capital letters are not significantly different $(p<0.05)$.

${ }^{2}$ Vrijednosti u istoj koloni označene istim velikim slovom ne razlikuju se na razini signifikantnosti od $(p<0.05)$.

mone promoted the germination in 8 -w pre-chilled seeds and increased the germination percentage. There was a distinctive difference between the germination percentage for the 8 -w pre-chilled and non-pre-chilled seeds (Figure 2).

\section{DISCUSSION AND CONCLUSIONS} RASPRAVA I ZAKLJUČCI

The seed cones of Syrian juniper are the largest of any juniper species(Yaltırik, 1988). In present study, the average cone length and diameter was found $22.49,20.86 \mathrm{~mm}$, respectively. In another study (Sobierajska et. al., 2016), aver- age cone length and cone diameter of J. drupacea for 12 populations was found 20.54 and $19.18 \mathrm{~mm}$, which were relatively similar to our results. The average number of seeds extracted from the cones was 2.2. There wasn't a statistical difference between the provenances in terms of cone length, diameter and seed number. In other two studies the average seed number was 2.1 (Gültekin et al., 2005) and 2.3 (Gürlevik and Gültekin, 2008).

In this study the average 1000 -seed weight was found 44.66 $\mathrm{g}$ for three provenances.1000-seed weight generally occurs between 10-90 $\mathrm{g}$ depending on the species and provenances (Bonner, 2008). In J. virginiana L. and J.occidentalis 


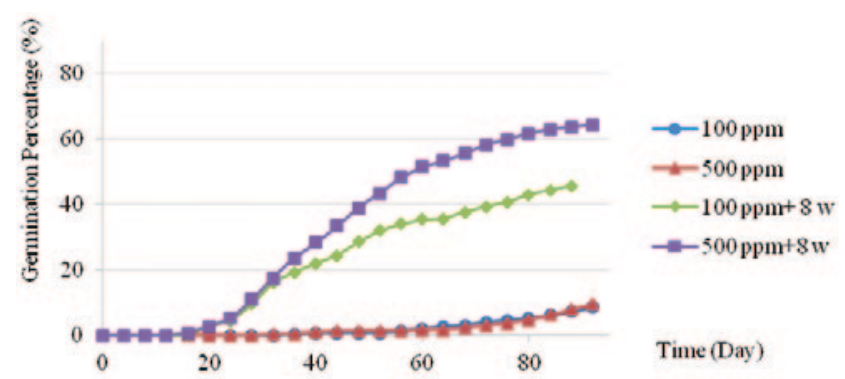

Figure 2. Germination curve of $J$. drupacea seeds exposed to $\mathrm{GA}_{3}$ hormone.

Slika 2. Krivulje klijavosti sjemena J. drupacea na koje je primjenjen hormon $\mathrm{GA}_{3}$.

Hook.1000-seed weight was 10.4 and 36.9 g respectively (Bonner, 2008).The average seed length, width, thickness and weight were found $10.07 \mathrm{~mm}, 3.30 \mathrm{~mm}, 2.77 \mathrm{~mm}$ and $0.045 \mathrm{~g}$, in order.

There were significant differences between the pre-treatments with regard to germination percentages. The seeds without any pre-treatments showed very low germination percentage (6\%). But after different pre-treatment's germination percentage was increased. This showed that J. drupacea seeds have deep dormancy. The applied pre-chilling treatments didn't entirely eliminate the dormancy. However the seeds for three provenances after 4 weeks warm stratification and subsequently 9 weeks pre-chilling were very effective on the elimination of dormancy and they increased the germination percentage (average 65.3\%). Barbour and Carvalho (2009) tried to germinate J. scopulorum Sarg. seeds with 21 different pre-treatment's. In that study they obtained the best results (55\%) with 16 weeks of warm stratification and 13 weeks cold stratification. For the above mentioned treatments they soak the seeds 3 days in water. Morphological and physiological seed dormancy is well recorded in many woody species: Fraxinus excelsior L. (Suszkaet al., 1996), Carpinus betulus L., Tilia cordata Mill., Juniperus communis L., Cornus mas L. (Gosling, 2007), Taxus chinensis (Pilg.) Rehder var. mairei (Lemée ex H. Lév.) W. C. Cheng et L. K. Fu (Chien et al., 1998) Juniperus excelsa M. Bieb.var. polycarpos (K. Koch) Takht. (Daneshvar, 2015), Prunus campanulata Maxim. (Chien et al., 2002), Viburnum lantana L. (Santiago et al., 2015) etc. To break this dormancy different pre-treatments are necessary, e.g.warm incubation and pre-chilling (Baskin and Baskin, 2004). The best results in our study in terms of mean germination time were achieved with 4 weeks of warm stratification and 9 weeks of pre-chilling.

It is well now that gibberellic acid breaks the dormancy, promotes germination and inhibits ABA effect in germination processes (Bewley and Black, 1994; Kucera et al., 2005). In our study non-pre-chilled seeds that were treated with $100 \mathrm{ppm}$ and 500 ppm $\mathrm{GA}_{3}$ showed very low germination percentages. On the other hand, 8 weeks pre-chilled seeds which were subjected to $\mathrm{GA}_{3}$ hormone reached the highest germination percentage (64.3\%). Gibberellic acid without any pre-treatments didn't have a significant effect on the germination of J. drupacea seeds.

$J$. drupacea is a decorative, evergreen tree with high ornamental potential. Considering that it could be used in parks and gardens as an ornamental species. Furthermore, J. drupacea seedlings should be produced in forest nurseries and used in reforestation programs.

\section{REFERENCES}

\section{LITERATURA}

- Adams, R. P., 2014: Junipers of the World: the genus Juniperus, 4th edn., Bloomington: Trafford Publ. Co., 415 pp., United States of America

- Barbour J.R., J.P.F. Carvalho, 2009: Response of Rocky Mountain Juniper (Juniperus scopulorum) seeds to seed conditioning and germination treatments, Seed Technol., 31:43-54

- Baskin, J.M., C.C. Baskin, 2004: A classification system for seed dormancy, Seed Sc1. Res., 14 (1):1-16

- Bewley, J.D., M. Black, 1994: Seeds physiology of development and germination, 445pp., New York

- Bewley, J.D., K.J., Bradford, H.W.M., Hilhorst, 2013: Seeds physiology of development, germination and dormancy, 392 pp., London

- Bonner, F.T., 2008: Juniperus L. In: The woody plant seed manual, (F. T. Bonner, R. P. Karrfalt), USDA Forest Service Agriculture Handbook 727, 607-614pp.Washington

- Broom, A., 2003: Growing juniper: propagation and establishment practises, Forestry Commission Information Note 50. Forestry Commission, Edinburgh

- Browicz, K., 1982: Chorology of trees and shrubs in South-West Asia and adjacent regions, Polish Scientific Publishers, 9pp., Poznan

- Brus, R., D. Ballian, P. Zhelev, M. Pandža, M. Bobinac, J. Acevski, Y. Raftoyannis, K. Jarni, 2011: Absence of geographical structure of morphological variation in Juniperus oxycedrus L. subsp. oxycedrusin the Balkan Peninsula, Eur. J. For. Res., 130: 657-670

- Brus, R., M. Idžojtić, K. Jarni, 2016: Morphologic variation in northern marginal Juniperus oxycedrus L. subsp. oxycedrus populations in Istria, Plant Biosyst.,150 (2): 274-284

- Chien, C., L. L. Kuo-Huang, T. P. Lin, 1998: Changes in ultrastructure and abcisic acid level, and response to applied gibberellins in Taxus mairei seeds treated with warm and cold stratification, Ann. Bot-London, 81 (1):41-47

- Chien, C., S. Chen, J. Yang, 2002: Effect of stratification and drying on the germination and storage of Prunus campanulata seeds, Taimwan J. For. Sci., 17 (4): 413-420

- Daneshvar, A., 2015: Improved seeds handling techniques for Juniperus polycarpus, Dissertation, Swedish University of Agricultural Sciences, Faculty of Forest Sciences, Alnarp

- Daneshvar, A., M. Tigabu, A. Karimidoost, P. C. Odén, 2016: Stimulation of germination in dormant seeds of Juniperus polycarpos by stratification and hormone treatments, New Forest., 47 (5): 751-761

- Douaihy, B., K. Sobierajska, A. K. Jasińska, K. Boratyńska, T. Ok, A. Romo, N. Machon, Y. Didukh, M. B. Dagher-Kharrat, A. Boratyński, 2012: Morphological versus molecular markers to describe variability in Juniperus excelsa subsp. excelsa (Cupressaceae), AoB Plants, pls013 
- Drvodelić, D., T. Jemrić, M. Oršanić, V. Paulić, 2015: Fruits size of wild apple (Malus sylvestris /L./Mill.): impact onmorphological and physiological properties of seeds, Sumar. list, 139 (3-4): 145-153

- Fenner, M.,K. Thompson, 2005: The ecology of seeds, Cambridge University Press, 260 pp., Cambridge

- Gosling, P.G., 2007: Raising trees and shrubs from seed, 28pp., Edinburg

- Gültekin, H.C., 2007: Andiz (Arceuthos drupacea (Labill.) Ant. Et. Cotschy) ve Fidan Üretim Teknikleri, 28pp., Ankara

- Gültekin, H.C., A. Gezer, N. Gürlevik, C. Yücedağ, Ü. G.Gültekin, A. Divrik, 2005:Andiz (Arceuthos drupacea Ant. Et. Kotschy) Tohumlarının Çimlenme Engelinin Giderilmesinde Kullanılan Önişlemler Üzerine Bir Araştırma, Süleyman Demirel Üniversitesi Fen Bilimleri Enstitüsü Dergisi, 9 (2): 84-89

- Gültekin, H.C, Ü. G. Gültekin, A. Divrik, 2004: Andız (Arceuthos drupacea (Labill.) Ant. et. Kotschy.) Tohumlarının Çimlenmesi, Diğer Tohum ve Fidan Özelliklerine İlișkin Bazı Tespit ve Öneriler, Artvin Çoruh Üniversitesi Orman Fakültesi Dergisi, 5 (1): 48-54

- Gürlevik, N., H. C. Gültekin, 2008: Katlama ve Mekanik Önişlemlerin Andız (Arceuthosdrupacea Ant. Et. Kotschy) Tohumlarının Çimlenmesi Üzerine Etkileri, Süleyman Demirel Üniversitesi Orman Fakültesi Dergisi,2 (2): 147-157

- ISTA, (1996): International rules for seed testing, Seed Sc1. Technol. (Supplement), 24: 1-335

- Kaplan, D. R., 2001: The science of plant morphology: definition, history, and role in modern biology. Am. J.Bot., 88: 1711-1741

- Kucera, B., M.A. Cohn, G. Leubner-Metzger, 2005: Plant hormone interactions during seed dormancy release and germination, Seed Sc1. Res., 15 (4): 281-307

- Polat, A. A., M. Özkaya, 2005: Selection studies on fig in the Mediterranean region of Turkey, Pak. J. Bot., 37 (3): 567-574

- Poljak, I., D. Kajba, I. Ljubić, M. Idžojtić, 2015: Morphological variability of leaves of Sorbus domestica L. in Croatia, Acta Soc. Bot. Pol., 84 (2): 249-259
- Poljak, I., N. Vahčić, M. Gačić, M. Idžojtić, 2016: Morphological characterization and chemical composition of fruits of the traditional Croatian chestnut variety 'Lovran Marron', Food Technol. Biotechnol., 54 (2): 189-199

- Powell, A. A., 2010: Morphological and physiological characteristics of seeds and their capacity to germinate and survive, Ann Bot. 105 (6): 975-976

- Al-Ramamneh, E. A., S. Dura, N. Daradkeh, 2012: Propagation physiology of Juniperus phoenicea L. from Jordan using seeds and in vitro culture techniques: Baseline information for a conservation perspective, Afr. J. Biotechnol. 11 (30): 7684-7692

- Santiago, A., P. Ferrandis J.M. Herranz, 2015: Non-deep simple morphophysiological dormancy in seeds of Viburnum lantana (Caprifoliaceae), a new dormancy level in the genus Viburnum, Seed Sc1. Res., 25 (1): 46-56

- Schmidt, L., 2000: Guide to handling of tropical and subtropical forest seed, 511pp., Denmark

- Sękiewicz, K., K. Boratyńska, M. B. Dagher-Kharrat, T. Ok, A. Boratyński, 2016: Taxonomic differentiation of Cupressus sempervirens and C. atlantica based on morphometric evidence, Syst. Biodivers., 14 (5): 494-508

- Sobierajska, K., K. Boratyńska, A. Jasińska, M. Dering, T. Ok, B. Douaihy, M. B. Dagher-Kharrat, A. Romo, A. Boratyński, 2016: Effect of the Aegean Sea barrier between Europe and Asia on differentiation in Juniperus drupacea (Cupressaceae), Bot. J. Linn. Soc., 180 (3): 365-385

- Suszka, B., C. Muller, M. Bonnnet-Masimbert 1996: Seeds of forest broadleaves from harvest to sowing, Institut National de la Recherche Agronomique, 295pp., Paris

- Vidaković, M., 1991: Conifers: morphology and variation, Translated from Croatian by Maja Soljan, Grafički Zavod Hrvatske, 754 pp., Zagreb

- Yaltırık, F., 1988: Dendroloji- Gymnospermae, İstanbul Üniversitesi Orman Fakültesi Yayınları, 320 pp., Istanbul

- Yilmaz, M., T. Yüksel, 2014: Morphological and physiological seed characteristics of Taurus fir (Abies cilicica /Ant. et Kotschy/Carriére) in Turkey, Sumar. list, 138 (11-12): 583-592

\section{Sažetak}

Sirijska smreka, Juniperus drupacea Labill. je istočno mediteranska vrsta stabla koja pripadaporodici Cupressaceae, roduJuniperoidae. J. drupacea trenutno pokriva geografsko područje južnog dijela Peloponeza u Grčkoj, južne dijelove Male Azije te sirijske i libanonske planine. Glavni dio područja te vrste u Turskoj podijeljen je na nekoliko središta, od kojih je najvažniji smješten u Taurskom gorju, Anti-Taurus gorju te planinama Amanos. Stablo je diecično, s konusnom krošnjom koja može doseći 10-20 (40) m visine. Mesnati češeri su ovalnog do okruglog oblika, 20-25 mm u promjeru, smećkasto-ljubičaste ili plavkasto-crne boje, te žućkasti i bjelkasti kada su zreli tijekom druge godine. Uglavnom imaju 3 sjemenke koje tvore karakterističnu košticu nalik na košticu koštičavog voća. Prirodna regeneracija sirijske smreke vrlo je teška zbog konzumacije od strane životinja, ispaše i sjemenki koje su objedinjene u drvenastu strukturu. Ovo je istraživanje provedeno kako bi se odredila morfologija sjemenke i češera te fiziologija sjemenke sirijske smreke, Juniperus drupacea Labill., koja potječe iz tri provincije (Kahramanmaraş, Mersin, Adana) u istočnomediteranskoj regiji Turske. Ukupno je izmjereno 11 morfoloških obilježja. Prosječna duljina češera bila je 22,49 mm, promjer češera 20,86 $\mathrm{mm}$, a težina češera $4,659 \mathrm{~g}$. Prosječna duljina, širina, debljina, težina sjemenke i težina pulpe sjemenke iznosile su redom 10,07 mm, 3,30 mm, 2,77 mm, 0,045 g i 2,220 g. Nakon morfološke analize, proveden je niz eksperimenata kako bi se odredila najbolja mjera stratifikacije radi prekidanja dormantnosti sjemenki sirijske smreke. Najveći postotak klijavosti dobiven je nakon tople i hladne stratifikacije (80,7\%). Sjemenke koje su se prethodno hladile 8 tjedana te su namakane u 500 ppm $\mathrm{GA}_{3}$ također su pokazale velik postotak klijavosti. Ovo je istraživanje također pokazalo da sjemeJ. drupaceaposjeduje morfološku dormantnost. 